Пространственная Экономика

2013. № 3. C. $178-183$

UDC 339

\title{
NEW WORLD ORDER \\ AND STRATEGIC INNOVATION \\ (on article of Yong-Chool Ha, Beom-Shik Shin "The Development of Russian Far East and Eastern Siberia and the Future of Northeast Asia")
}

\section{Taco C.R. van Someren, Shuhua van Someren-Wang}

Taco C.R. van Someren - Doctor of Economics, Professor. Ynnovate, 45 Acaciapark, 1213 LC Hilversum, Netherlands. E-mail: tcrvansomeren@ynnovate.com.

Shuhua van Someren-Wang - Doctor of Economics. Ynnovate, 45 Acaciapark, 1213 LC Hilversum, Netherlands. E-mail: tcrvansomeren@ynnovate.com.

\section{NEW WORLD ORDER}

With the economic rise of BRIC countries with China and the Russia playing an important role, while the Western economy fights one crisis after another, a new world order is being shaped [2]. The new world order will differ from the current Western dominated ideas and vales in many ways. Illustrative is the new relation between China and Russia. After his appointment as President of China Mr. Xi Jinping immediately visited Russia. It is a recent tradition that Chinese leaders first have a meeting with the Russian President before travelling to other world leaders. But time has changed and the main reason for these visits to neighbors has changed. In former times the political relation and sometimes tension due to different interpretations of the communistic path to welfare got priority. Now and in the coming years the main issues are both economic and long term interests of stable relationship. Xi and Putin stress the strategic relationship between Russia and China and the importance of strategic cooperation. In this respect regional frameworks such as the ratification of the 2013-2016 implementation guidelines of the China-Russia Treaty of Good-

(C) Taco C.R. van Someren, Shuhua van Someren-Wang, 2013 
Neighborliness and Friendly Cooperation illustrate the creation by purpose of a new world order. The planning of the first foreign trip of Xi demonstrates the shifting power. Directly after visiting Russia, Xi moves on to Tanzania, South Africa and the Republic of the Congo where China has increasing interest in natural resources.

This new world order consists of elements which each differ on their own but taken together will lead to a consistent new world system. Elements of this new world order are for example norms and values, ways of doing business, access to resources, cultural institutions like religion, concepts of time, economic behavior and the role of government and private enterprises [2]. For example, the Western world order is based on Christianity. The influence of its thinking can be found back in economic system of Input-Throughput-Output based on the linear Christian Birth-Life-Death development. Circular time based concepts, which are present in Chinese culture, leading to new notions such as sustainability have been absent for 2,000 years. Another relevant aspect is the free market economy based on private enterprises and innovation from the bottom (the individual or single enterprise) opposed to government led top down planned economy. The initial success ultimately created the unilateral dominance of the US as a single super power and followed by a struggling EU. Due to the rise not only of China but also Russia, Brazil, India, South Africa, Turkey, Indonesia and other nations the multipolar world will take over from the current unilateral world. Moreover, other political-religious-economic thinking is gaining power and influence. But the precondition for new nations taking over is an economy with a substantial earning power and the ability to act on a global scale. The latter is also relevant from the viewpoint of natural resources. The increase of the world population and especially their increasing demand for goods and services creates a demand for resources. Despite innovation, some of these resources are becoming scarce like (drinking) fresh water, rare earth materials and land suitable for agro-food exploitation. The current free market economy for acquiring resources, sometimes dominated by powerful private companies like Cargill, is not sufficient anymore to satisfy the demand. Other supply-demand governance principles such as acquiring land for food production and monopolizing mining areas replace the free market. Often the emergence of Chinese and Russian in these scenes is accompanied by a new symbiosis between public and private organizations. These closer relationships take over from the Western separation between private and public organizations. The West invests all their money in saving banks whereas the East invests in securing and access to resources.

This context of a rising new world order is the relevant background of future Russian-Chinese relations. Even more important, the features of the new world order will have great influence on any possible cross border activities or attempt to create any cooperation between cross nation regions like a consortium of Northeast Asian community. 
№ 32013

\section{WHY RUSSIA AND CHINA NEED EACH OTHER}

The world is on a cross road. The old economic growth-curve is going down and the new comers are growing up. If the right path is chosen, the new growth wave can take the world economy out of the misery. The cross road mainly consists of the coexistence, cooperation or competition between the West and the emergent other countries. Among others, leading nations from the emergent countries will be China and Russia. As individual nations they already make a difference for the world economy. But together they will form a countervailing power to the EU and the US.

Just like the relationship between China and the West, the interdependence of Russia and China will no longer only based on the geopolitical reasons. It can be summarized in the 5 M's. They are respectfully "Mutuality", "Money", "Markets", "Manpower" and "Mentality" [2]. Russia and China need each other's "Mutuality" not only in the international community but also in reducing regional unrest to protect their economic interests. Russia and China need each other's "Money" because cross-border investment is becoming crucial for both economies. Especially when the Chinese are cornered by devaluation of both Dollar and Euro while the inland overinvestment bubble is threatening almost every sector. But at the same time, real innovation from the private sector is not financially well supported by the state-owned or -directed banks. The crush of the export sector also dries up the venture capitals. Russia and China need each other's "Market". The "Market" of both countries is still underdeveloped for each other. Low-added value is still the norm. At the same time the purchase power of the people are increasing. Russia and China need each other's "Manpower". It is a pity that too many Russian and Chinese talents are seeking their fortune in the West while both countries need those talents. Only a strong joint economy can attract those talents. Russia and China also need each other's "Mentality". Each country chose a different way of economic reform and learned their lessons. They can benefit a lot from each other's lessons.

But in order to satisfy the demand of their population for a higher welfare, goods and services resources security becomes a key issue. In the future world, resource security is less a domestic issue and increasingly a worldwide search and competition to get access to the needed materials and substances. Furthermore, it might be luck or coincidence, both the Eastern part of Russia and the Northern part of China possess natural resources. Exploration and exploitation is still underdeveloped and can be expanded. In order to be able to act on a world scale regional stability avoiding political unrest or even war is a prerequisite for global expansion and resource assurance. Trouble in the backyard hampers global economic expansion. But resources and regional stability should not be the only reason Russia and China 
need each other. An intensified relation by means of cross border cooperation forces the two nations to cooperate and to find mutual interests like the 5 M's. The new approach means that a strategic innovation needs to be created leading to new wealth and opportunities for both countries, the region and the world.

\section{STRATEGIC INNOVATION}

In the long term, everyone expects China to become the new world leader and biggest nation. But the West has not lost yet. On the contrary, the West can still be the winner. Why the West has still chances to be even the winner? China (and India) will become the biggest nation because of size of the population. China will overtake as a nation with the biggest GDP and economy (Gross Domestic Product). But these two macro-indicators are not sufficient to become the Future Leader of the New World Order. One of the main Russian industries is exploration and exploitation of natural resources. Other sectors are less developed or less modernized like agro food and automotive sector. China created its wealth by being the world's manufacturing workshop and earning money with high volume low added value production facilities. Both countries need to renew themselves by means of strategic innovation. Ultimately the ability to create something new will be decisive about which nation or leading domestic industries and its enterprises will be the future dominant world players. Both nations have to apply strategic innovation to create new wealth opportunities and industrial power. In the Western world, the last years many industries discovered the importance of creating new business models. Business models are a systematic combination of new products, processes, clients, distribution and other aspects of a market based enterprise leading to future earning power or profits [1;4]. For example, selling by Internet («bricks and clicks») requires another business model than selling from a shop in a shopping mall («bricks and mortar»). But with the emergence of a new world order, creating new business models are not sufficient anymore [2; 3]. Instead strategic innovations are becoming far more important. The strategic innovations consist of four elements: leadership, institutional innovation, business development and governance. Future leadership requires the ability to be a world leader and to deal with different political-economic systems. Moreover, the main task of a future business leader is not to create shareholder value but to create a context for innovation. Institutional innovation is the ability of any organization to constantly create new products, technology, new client relationships and cross border activities. Business development is the task to create world markets and sell any innovation. Future governance will shift from corporate governance to industrial governance reflecting the closer relationship between private and public sector. Any Russian-Chinese relationship or consortium will have to deal with these elements of strategic innovation which go beyond creating new business models. 
№ 32013

\section{RELEVANCE OF STRATEGIC INNOVATION FOR RUSSIAN FAR EAST AND EASTERN ASIA}

When we apply the above mentioned game changing issue of strategic innovation in the context of a new world order the contribution of $\mathrm{Ha}$ and Shin can be reviewed as follows. The basic idea of Ha \& Shin about developing a Far East Asian zone is attractive due to its potential. Ha \& Shin propose to work from the underdeveloped linkage between economics and security in the political sense. Till here we agree but there are several missing links in their framework and way of thinking. First, the sense of urgency or decisive driving force for a closer cooperation (consortium) is missing. As long this stays unclear, some minor projects might be started but the breakthrough will be absent. Second, Ha \& Shin do not show in which fields the local eastern economies can reinforce each other or what to their opinion the link between economy and security is. Only qualitative conditions for a plan such as comprehensiveness, balance and others are mentioned. It remains unclear what the actual added value of such a plan is. Third, in their analysis, the suggestion of Ha \& Shin does not mention innovation at all. As shown above, based on the current situation, innovation is the most important element for future success in particular cross border cooperation. Fourth, the focus of Ha \& Shin is on economic interaction within a political cultural context which boils down to a kind of cross border economic interest governed by a 'consortium'. But their approach does not address the crucial strategic innovation issues of global leadership, institutionalized innovation, business development and industrial governance. Fifth, in fact Europe does not exist, it is adding up totally different countries by size and culture. Germany and increasingly to a lesser extent dominate the European scene. The same holds for Eastern Asia. China and Russia will dominate the Far East but they will be rivaled by India. Other smaller countries will have different interests and oppose the majors. Therefore, not only cultural differences but also economic and other interests have to be dealt with in order to create a successful cooperation. Ha \& Shin do neither address these relevant difference between potential members of the cooperation or Far East community nor how to deal with it.

The approach of strategic innovation provides the right framework for establishing a cross border cooperation driven by the modus operandi of dynamic value creation. Strategic innovation solves the above mentioned missing links of the approach of $\mathrm{Ha}$ and Shin. The Strategic Innovation Theory has been applied to create consortia and cross border cooperation. Among others, examples are the agro-food industry and the cooperation between Germany, Belgium and The Netherlands in creating a top innovation region $[2 ; 3]$. 


\section{REFERENCES}

1. Someren T. C. R. van. Innovation, Emulation and Time. The Role of the Organisational Reforms in the Economic Process.Tinbergen Institute. Research Series. No. 9. Thesis Publishers. Amsterdam, 1991. (In Dutch).

2. Someren T. C. R. van, Someren-Wang S. Green China. Sustainable Growth in East and West. Heidelberg: Springer Verlag, 2012.

3. Someren T. C. R. van, Someren-Wang S. Innovative China. Innovation Race between East and West. Berlin: Springer Verlag, 2013.

4. Someren T. C. R. van. Strategic Innovations. So Make Your Business Unique. Gabler Verlag, Wiesbaden, 2005. (In German).

5. Yong-Chool Ha, Beom-Shik Shin. The Development of Russian Far East and Eastern Siberia and the Future of Northeast Asia. Prostranstvennaya Ekonomika - Spatial Economics, 2013, no. 2, pp. 10-21.

\section{НОВЫЙ МИРОВОЙ ПОРЯДОК И СТРАТЕГИЧЕСКИЕ ИННОВАЦИИ (о статье Ён-Чул Ха, Бом Сик Шина «Развитие российского Дальнего Востока и Восточной Сибири и будущее Северо-Восточной Азии»)}

\section{Тако С.P. ван Сомерен, Шухуа ван Сомерен-Ванг}

Тако С.P. ван Сомерен - доктор экономических наук, профессор, владелец компании Ynnovate. Хилверсюм, Нидерланды. 45 Acaciapark, 1213 LC Hilversum, Netherlands. E-mail: tcrvansomeren@ynnovate.com.

Шухуа ван Сомерен-Ванг - доктор экономических наук, партнер компании Ynnovate. Хилверсюм, Нидерланды. 45 Acaciapark, 1213 LC Hilversum, Netherlands. E-mail: svansomeren@ ynnovate.com.

\section{СПИСОК ЛИТЕРАТУРЫ}

1. Someren T.C.R. van. Innovatie, Emulatie en Tijd. De rol van de organisatorische vernieuwingen in het economische proces / Tinbergen Institute. Research Series. № 9. Thesis Publishers. Amsterdam, 1991.

2. Someren T.C.R. van, Someren-Wang S. Green China. Sustainable Growth in East and West. Heidelberg: Springer Verlag, 2012.

3. Someren T.C.R. van, Someren-Wang S. Innovative China. Innovation Race between East and West. Berlin: Springer Verlag, 2013.

4. Someren T.C.R. van. Strategische Innovationen. So machen Sie Ihr Unternehmen einzigartig. Gabler Verlag, Wiesbaden, 2005.

5. Yong-Chool Ha, Beom-Shik Shin. The Development of Russian Far East and Eastern Siberia and the Future of Northeast Asia // Пространственная экономика. 2013. № 2. C. 10-21. 